Pécsi Tudományegyetem, Általános Orvostudományi Kar, Arc-, Állcsont- és Szájsebészeti Tanszék*

Pécsi Tudományegyetem, Általános Orvostudományi Kar, Klinikai Központ I. sz. Belgyógyászati Klinika**

Pécsi Tudományegyetem, Általános Orvostudományi Kar, Gyermek- és Ifjúsági Fogászati Tanszék***

\title{
Magas inhibitor titerú B-haemophiliás beteg fogorvosi-szájsebészeti ellátása
}

\author{
Esetismertetés
}

DR. VAJTA LÁSZLÓ*, DR. NAGY ÁGNES**, DR. KÁLOVICS JUDIT***, DR. SZALMA JÓZSEF*

\begin{abstract}
Jelenleg 1000-nél is több haemophiliás férfibeteget tartanak számon hazánkban. Ezen betegek relatíve kis része úgynevezett inhibitoros haemophiliában szenved. A haemophiliás betegek fogorvosi-szájsebészeti ellátása haematológiai kooperációt igénylő feladat, mely során a biztonságos kezelés kizárólag a többlépcsős, vérzéscsillapítási elveket betartva végezhető. Szerzők esetismertetésük során egy magas inhibitor titerű B-haemophilias beteg haematológiai együttmúködést igénylő, fogorvosi-szájsebészeti ellátását mutatják be, majd részletezik az irodalomban található lokális vérzéscsillapító módszereket.
\end{abstract}

Kulcsszavak: vérzékenység, haemophilia, faktorpótlás, vérzéscsillapítás, desmopressin, tranexámsav

\section{Bevezetés}

Pácienseink, akik valamilyen vérzékenységgel járó betegségben szenvednek, fogászati és különösen szájsebészeti szempontból kockázatot jelentenek a fogorvosok számára. A súlyos, beavatkozás közbeni és posztoperatív vérzés esélyét, illetve az idősebb betegeknél esetlegesen fennálló vírusos májgyulladást (vagy más eredetű májkárosodást) is figyelembe kell venni a beavatkozások megtervezésénél, kivitelezésénél. Sajnálatos módon a haemophiliás betegek fogászati prevenciója Magyarországon nem megoldott, ellátásuk nem rutinszerű, legfőképp alapellátási körülmények között. Jelenleg Magyarországon 1000-nél is több haemophiliás férfibeteget tartanak számon, akik közül $80 \%$ „A” típusú, míg 20\% „B” típusú haemophiliában szenved. A haemophilia „A” a VIII-as véralvadási faktor (FVIII) $X$ kromoszómára lokalizálódó génjében bekövetkező mutáció következtében létrejövő veleszületett vérzékenység. A IX-es faktor (FIX) génje ugyancsak az X kromoszómán helyezkedik el, mutációi okozzák az úgynevezett „B” típusú haemophiliát. Haemophila „A” (VIII-as faktor hiány) esetén az esetek nagyságrendileg harmadában, míg haemophilia „B” (IX-es faktorhiány) esetén az esetek 3-5\%-ában áll fent inhibitoros (gátlótestes) hemophilia. Invazív (vérzéssel járó) beavatkozások kivitelezésekor különösen veszélyeztetettek az inhibitoros haemophiliások, hiszen a korábbi faktorpótlás során képződött, vérben keringő antitestek miatt a rutinszerü szubsztitúcióval szemben rezisztensek, továbbá súlyos anaphylaxiás szövődmény is kialakulhat [1, 3, 9].

\section{Esetismertetés}

Ismert, súlyos, korábban magas inhibitor titerú (64 Bethesda egység) B-haemophiliás 28 éves beteg (F. IX.aktivitás $<1 \%$ ) jelentkezett egyetemünk haematológiai osztályán (PTE KK I. sz. Bel. Klinika) korábban már többször előforduló ínyvérzéssel, továbbá a jobb alsó állcsonti quadránsban jelentkező kisugárzó fájdalommal. Anamnézisében többszöri nagyízületi, illetve végtagokon jelentkező bevérzés, többszöri epitaxis, jobb és bal oldali térdizületi synovectómia, nephrolithiasis okozta macroscopos haematuria, korábbi F. IX. készítmény beadását követő anaphylaxia szerepelt. Haematológus kolléganő (Dr. Nagy Ágnes) dentoalveoláris konzíliumot kezdeményezett. Ennek során fizikális- és röntgenvizsgálattal a jobb alsó bölcsességfog impaktált (beékelődött) helyzetét, következményes lágyszöveti gyulladást és a második moláris fog disztális felszínének szuvasodását állapítottuk meg, köszönhetően a bölcsességfog rendellenes helyzetéből adódó lepedékretenciónak (1. ábra). A nem kielégítő szájhigiéniából fakadóan ínygyulladást és kezdődő fogágybetegséget találtunk (gingivitis és parodontitis chronica).

Haematológus kollégával történt megbeszélést követően az eset megoldására alapos supra- és subgingivális fogkő-eltávolítást (kiegészítve szájhigiénés instruálással és motiválással), a 4.8-as beékelődött bölcsességfog preventív mútéti eltávolítását és a 4.7-es fog disztális felszínén lévő szuvasodásának konzerváló fogászati ellátását indikáltuk. Tekintettel az előző beavatkozások során esetlegesen fellépő vérzéses szö- 


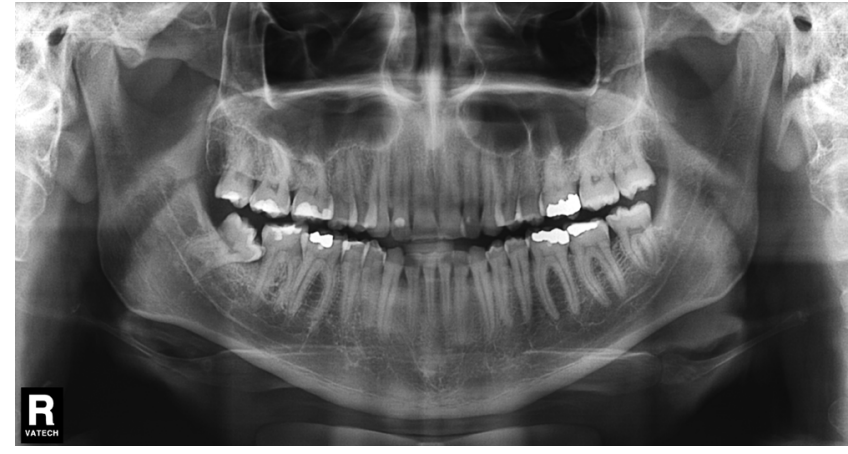

1. ábra: A páciens panoráma röntgenfelvételén láthatjuk, hogy a fogazat megtartott, restaurált. A 4.8-as fog (bölcsességfog) mezioanguláris helyzetben impaktált és a 4.7-es második őrlőfog disztális felszínének dől, tisztíthatatlan fogfelszíneket létrehozva.

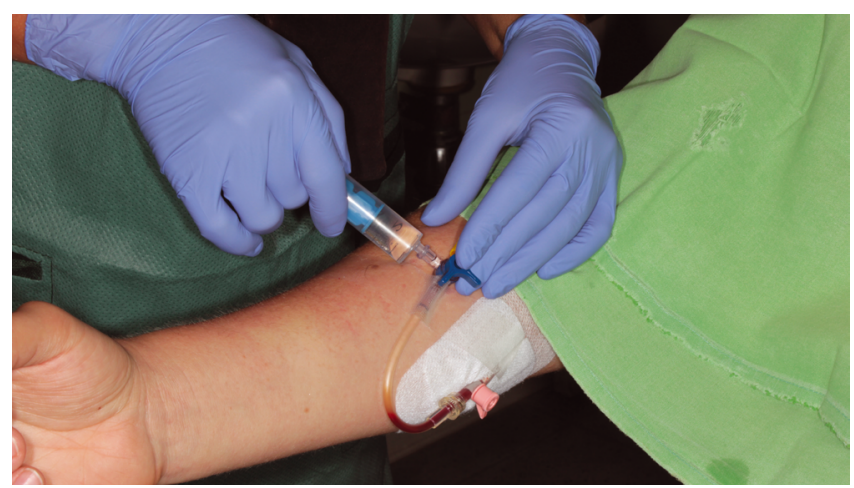

2. ábra: NovoSeven ${ }^{\circledR}$ készítmény intravénás adása a beavatkozás megkezdése előtt 20 perccel

vődményre, valamint az F. IX. adását követően várható anamnesztikus válaszra (magas inhibitor titer és anaphylaxia), aktivált, rekombináns VII-es faktor (rFVIla, NovoSeven ${ }^{\circledR}$; Novo Nordisk, Bagsvard) adása mellett végeztük a parodontológiai, szájsebészeti beavatkozásokat (2. ábra).

Első lépésben alapos fogkő-eltávolítást végeztünk ultrahangos depurátor segítségével, melyet polírozás követett. Ezen beavatkozást követően az ínyszél mentén szivárgó vérzés jelentkezett (3. ábra).

Közvetlenül a dentálhigiéniai kezelés után, vezetéses és infiltrációs helyi érzéstelenítés mellett (LIDOCAINADRENALIN $20 \mathrm{mg} / \mathrm{ml}, 0,01 \mathrm{mg} / \mathrm{ml}$ oldatos injekció, Egis)

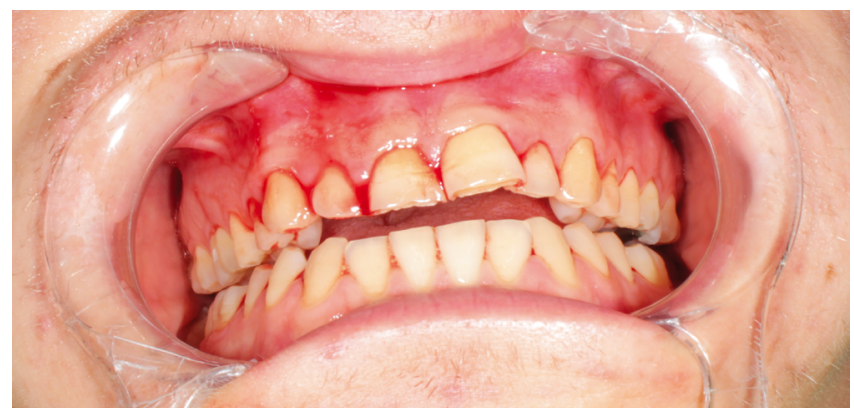

3. ábra: Fogkő-eltávolítást követően jelentkező diffúz, ínyszéli vérzés

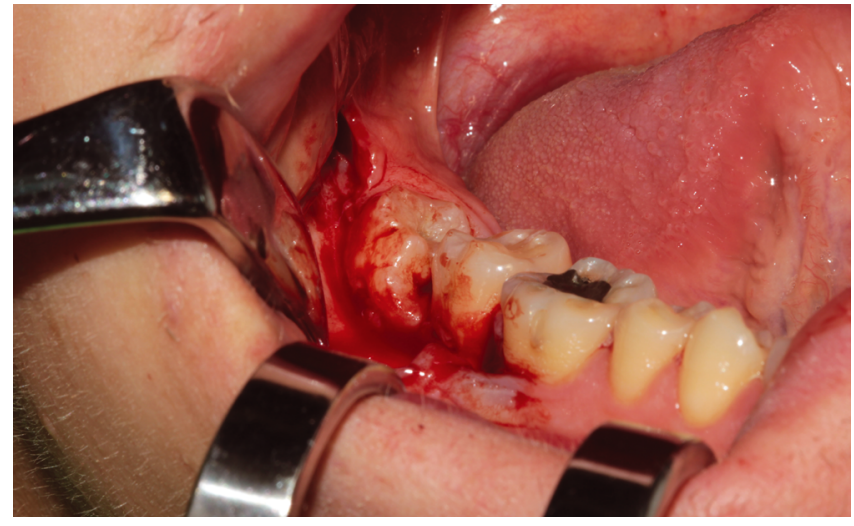

4. ábra: A bölcsességfog eltávolítása, szulkuláris, mukoperioszteális lebenyalakítást követően

sebészi feltárásból elvégeztük az impaktált bölcsességfog szekcionált eltávolítását (4. ábra). Ezt követően az alveolusból diffúz vérzés jelentkezett, melyet kollagénszivaccsal (Spongostan ${ }^{\mathrm{TM}}$, Ethicon, Johnson \& Johnson) és felszívódó varróanyaggal (Coated Vicryl ${ }^{\circledR}$, Ethicon, Johnson \& Johnson) történő sebzárással csillapítottunk (5., 6. ábrák). A fogakat és a mütéti területet parodontális pakolással PeriPac (GC America Inc.) fedtük 3 napig, ami meggátolta az ínyszélből és a mütéti területből szivárgó vérzést. Készenlétben állt fibrinragasztó (Tissucol Kit ${ }^{\circledR}$, Baxter), használatára azonban

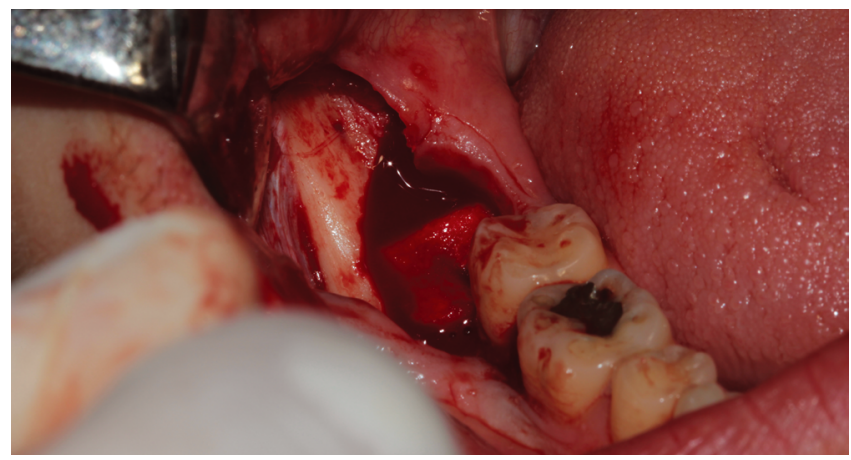

5. ábra: Az eltávolított bölcsességfog alveolusának feltöltése kollagén szivaccsal

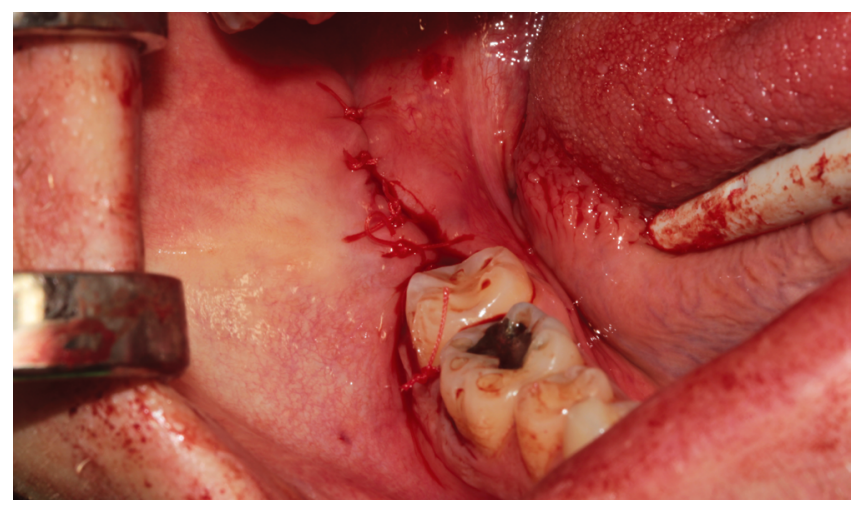

6. ábra: A mútéti terület per primam, résmentes sebzárása felszívódó varróanyaggal, egyszerủ csomós öltésekkel 
nem volt szükség. 30 perces vérzéskontrollt követően, a megbeszéltek szerint, a beteget visszairányítottuk a haematológiára obszerváció céljából.

Az intravénásan adott NovoSeven ${ }^{\circledR}$ injekciót $90 \mu \mathrm{g} /$ ttkg dózisban alkalmaztuk (dózisintervallum: 2 óra az első 48 órában, 3 óra a 3., 4., 5. és 6. postoperatív napon, 4 óra a 7., 8. és 9. postoperatív napon). Összesen 62 alkalommal kapott NovoSevent ${ }^{\circledR}$ (összdózis: $501 \mathrm{mg}$ ).

Beavatkozások után az infekciós szövődmények elkerülésére egy hétig per os antibiotikum terápiát (Tabl. Augmentin Duo, 1000 mg, 2 × 1; GlaxoSmithKline), analgetikumként per os paracetamolt (Tabl. Panadol, 500 mg, $3 \times 1$; GlaxoSmithKline) és klórhexidines öblögetést (napi $4 \times$ Corsodyl, $2 \%$; GlaxoSmithKline), antifibrinolítikumként per os tranexamsavat (Tabl. Exacyl, 500 mg; Sanofi-Aventis) és napi 4-5-szöri, hígított tranexámsavas (Inj. Exacyl 500 mg, 5 ml fiziológiás sóoldattal 10 ml-re hígítva, 2 percig a szájüregben tartva) öblögetést indítottunk a postoperatív vérzés elkerülése érdekében. Továbbá a beteget elláttuk steril gézlapokkal és fiziológiás sóoldattal (Inj. Salsol, $10 \mathrm{ml}$; Teva Gyógyszergyár) a szükség szerinti kompressziós vérzéscsillapításhoz. A beavatkozásokat követő 5. napon nagyméretű, instabil véralvadékkal jelentkezett szájsebészetünkön, melyet fiziológiás sóoldattal átitatott gézlappal óvatosan eltávolítottunk, majd az áthajlásba lokális vérzéscsillapítás gyanánt $2 \mathrm{ml}$ tonogénes lidocain (LIDOCAIN-ADRENALIN $20 \mathrm{mg} / \mathrm{ml}, 0,01 \mathrm{mg} / \mathrm{ml}$ oldatos injekció, Egis) és $2 \mathrm{ml}$ etamsylate (Inj. Dicynone, 125 mg/ml; Teva Gyógyszergyár) elegyét infiltráltuk. Ezután a szivárgó vérzés megszűnt. 10 napos obszerváció során a beteg transzfúziót nem igényelt, hemoszubsztitúcióra nem szorult, kardiálisan mindvégig stabil volt, tromboembóliás szövődményt nem észleltünk. Panaszmentes állapotban otthonába bocsátottuk, az esetleges postoperatív vérzés elhárítása végett $80 \mathrm{mg}$ NovoSeven ${ }^{\circledR}$ készítménnyel elláttuk (javasolt adagolás: $8 \mathrm{mg}, 2 \times 1$ ). A 3.7-es fog carológiai ellátására 1 hónappal a mútétet követően - elkerülve az esetleges haematomaképződést okozó vezetéses érzéstelenítést intraligamentális, artikain tartalmú érzéstelenítő szerrel (Inj. Ubistesine forte 4\%, 3M Espe) - került sor.

\section{Megbeszélés}

Haemophiliás betegek fogászati-szájsebészeti ellátása kizárólag a fogorvos és a haematológus szakorvos szoros együttműködésével valósítható meg. Részletes - a tervezett invazivitás fokát, a kezelés időtartamát is tartalmazó - fogorvosi szakvéleményt követően a haematológus a haemophilia súlyossági fokának megfelelően előkészíti a beteget a tervezett beavatkozásokhoz, hiszen már enyhe haemophiliában (faktorszint: 5-40\%) is bekövetkezhet súlyos vérzés a mútéti területen. Különös körültekintéssel kell eljárni középsúlyos haemophiliában (faktorszint: 1-5\%), illetve súlyos haemophiliában (faktorszint: 1\% alatt). Míg előbbi esetén súlyos vérzés csak traumánál és mútéti beavatkozásnál alakulhat ki, utóbbinál a spontán jelentkező izületi és izomközti vérzések következtében adekvát profilaxis nélkül hosszú távon kialakul a jellemző mozgáskorlátozottság a nagyizületek haemophiliás arthropathiájával, tengelyeltérésekkel, perifériás neuropathiával és izomatrófiával. Súlyos heamophiliában szenvedő betegeknél már egy egyszerü, vezetéses érzéstelenítés és az altatást megelőző intubáció is nagyméretű - akár a felső légutakat komprimáló - haematoma-képződéssel és vérzéssel járhat megfelelő szubsztitúció nélkül [1, 3, 7, 9, 13, 18].

A haemophilia kezelésének alapja a hiányzó véralvadási fehérje pótlása (szubsztitúció, faktorpótlás), ami jelenleg kizárólag intravénás úton történhet. $A$ vérzések kezelésére, illetve prophylaxis céljából plasma eredetü és rekombináns készítmények használhatók. Inhibitor képződéssel járó haemophiliában a korábban alkalmazott VIII-as és IX-es faktor hatástalan, ilyen esetben csak bypass készítmények (például: rFVIla, Novoseven ${ }^{\circledR}$ ) adhatók. Az rFVIla magas koncentrációban kötődik az aktivált thrombocyták sejtmembránjához, a X-faktort Xa-faktorrá alakítja át, aktivált FIX- és FVIII-hiányban is. Az aktivált vérlemezke felszínén képződött Xa-faktor elegendő trombinképződést biztosít a szöveti faktor és az FVIla kapcsolódásának helyén. Továbbá az esetleges infekciós szövődmény kialakulása is minimálisra csökken [4, 9, 11, 12, 14, 15].

Enyhe és középsúlyos heamophiliában alternatív lehetőségként felmerülhet a költséges szubsztitúciós terápia helyett szintetikus antidiuretikus hormon, Desmopressin (DDAVP,1-deamino-8-D-arginine, vasopressin) intravénás, per os vagy transznazális alkalmazása. A DDAVP emelve a VIII-as és a von Willebrand-faktorszintet (az alapszint 2-8 szorosára) hatékonynak bizonyul haemophiliás betegek ellátása során [1, 7, 9, 13].

Antifibrinolítikus terápia is nagymértékben hozzájárul a hatékony vérzéscsillapításhoz. Tranexamsav meggátolva a plazminogén-plazmin aktivációját manapság első körben alkalmazandó szer a koagulum stabilizálásában. Szisztémás adagolás esetén használható intravénásan (Inj. Exacyl, Sanofi-Aventis), tabletta formájában (Tabl. Exacyl, Sanofi-Aventis) vagy lokálisan, oldat formájában (5\%-os tranexamsav 2 percig a szájban tartva napi 4 alkalommal, 3-7 napig). Elérhetők továbbá amino-kapronsav ( $\varepsilon$-amino-kapronsav, 6-amino-kapronsav) tartalmú készítmények is (Gran. Acepramin ${ }^{\circledR}$, PannonPharma) $[1,2,4,6,9,18]$.

Nemcsak a vérzés csillapításában és a költségek csökkentésében, hanem a sebgyógyulásban is segítségünkre lehet fibrinragasztó (Tissucol Kit, Baxter) használata. A Tissucol egy kétkomponensü szövetragasztó. A komponensek (Tissucol por - Aprotinin oldószer, Trombin por - Kalcium-klorid oldószer) gyártó utasítása szerinti összekeverését követően kiválóan használható vérzéscsillapításra, szövetlezárásra vagy -ragasztásra és sebek gyógyulásának elősegítésére [17].

A RICE mozaikszó (rest, ice, compression, and elevation) érthetően leírja az egyéb lokális vérzéscsilla- 
pítási módszereket, melyek hatékonyan alkalmazhatók haemophiliás betegek ellátása során. A beteget otthonában vagy a haematológiai osztályon nyugalomba kell helyezni (Rest), a mútéti területet és környékét jegelni kell (Ice), a mútéti területet fiziológiás sóoldattal, illetve műanyag, kivehető lemezekkel komprimálni kell (Compression), valamint a fejet emelt pozícióba kell helyezni (Elevation). Célszerű továbbá az éles csontszélek gömbfrézerrel történő elsimítása, a mútéti területre önmagában vagy trombin porral (Thrombostat ${ }^{\circledR}$, Pfizer) bevont, esetleg trombin oldattal (Topostasine ${ }^{\circledR}$, Roche) átitatott kollagénszivacs vagy háló helyezése, felszívódó atraumatikus varróanyaggal per primam sebzárás és lehetőség szerint parodontális pakolás használata. Esettől függően szóba jöhet továbbá kompressziós, müanyaglemezek használata is. Mindezek csökkentik a beavatkozás utáni vérzés és haematoma kialakulásának kockázatát $[1,4,9,13,18]$.

Fájdalomcsillapításra nem ajánlott a rutinszerűen adott nonsteroid adagolása. Ezen gyógyszerek egy része a COX-1 enzim gátlásán keresztül beavatkozhat a véralvadás folyamatába. Az antitrombotikus hatással nem rendelkező paracetamol/acetaminophen és codein alkalmazása biztonságos és hatékony alternatív megoldást jelent. Fentiekre adott allergiás reakció esetén a szelektív COX-2 gátlók adása is szóba jöhet [5, 8, 9, $10,16]$.

\section{Köszönetnyilvánítás}

Ezúton köszönöm Szabó Mártának (Novo Nordisk Hungária Kft.) a publikáció elkészítésében nyújtott segítségét.

\section{Irodalom}

1. Anderson Ja, Brewer A, Creagh D, Hook S, Mainwaring J, MckerNAN A ÉS MTSAI: Guidance on the dental management of patients with haemophilia and congenital bleeding disorders. Br Dent $J$ 2013; 215: 497-504.

2. Carter G, Goss A: Tranexamic acid mouthwash - a prospective randomized study of a 2-day regimen vs 5 day regimen to prevent postoperative bleeding in anticoagulated patients requiring dental extractions. Int J Oral Maxillofac Surg 2003; 32: 504-507.
3. Giangrande PLF: Managment of haemophilia. Pediatr Child Health 2011; 21: 344-347.

4. Heiland M, Weber M, Schmelzle R: Life-threatening bleeding after dental extraction in a hemophilia A patient with inhibitors to factor VIII: a case report. J Oral Maxillofac Surg 2003; 61: 1350-1353.

5. Joób FÁ, Barabás JB, Horváth CS, KaLmár G, Koppány F: Véralvadásgátló gyógyszerek alkalmazásának aktuális kérdései a fogorvosi és szájsebészeti kezelések során. Fogorv Szle 2008; 101: 147153.

6. KACHELMAN S, LŐRINCZ Á, JoÓB FÁ: Antikoaguláns kezelésben részesülő betegek szájsebészeti ellátásának klinikai vizsgálata. Fogorv Szle 2012; 105: 53-58.

7. Katz JO, Terezhalmy GT: Dental management of the patient with hemophilia. Oral Surg Oral Med Oral Pathol 1988; 66: 139-144.

8. Lockhart PB, Gibson J, Pond SH, Leitch J: Dental management considerations for the patient with an acquired coagulopathy. Part 2: Coagulopathies from drugs. Br Dent J 2003; 195: 495-501.

9. Magyar Transzfúziológiai és Hematológiai Szakmai Kollégium és Tudományos Társaság: NEFMI szakmai irányelv - a hematológiai betegségek korszerú kezelése. Egészségügyi Közlöny 2011; 18: 1-69.

10. Magyar Thrombosis és Haemostasis Társaság; Transzfúziológiai és Haematológiai Szakmai Kollégium: A thromboembólia kockázatának csökkentése és kezelése. Orv Hetil 2009; 150: 2335-2404.

11. Miskolczı SZ, VAszily M, Papp CS, PÉterffFy Á: Tapasztalataink a rekombináns faktor VIla-val (NovoSeven ${ }^{\circledR}$ ) a magas kockázatú szívmütétek vérzéses szövődményeinek kezelésében. Magy Seb 2008; 61(Suppl.): 45-47.

12. Moravcsik B, Nemes L, Zsiros L: Rekombinált aktivált VII-faktor alkalmazása veleszületett XI-es faktorhiányban szenvedő két nőbeteg vérzéses szövődményének kezelésében, megelőzésében, ortopéd sebészeti, ill. traumatológiai beavatkozás során. Esetismertetések. Orv Hetil 2008; 149: 1565-1568.

13. Morimoto Y, Yoshioka A, Imal Y: Haemostatic Managment of multiple tooth extraction in patients with haemophilia. Asian J Oral Maxillofac Surg 2008; 20: 184-188.

14. Morimoto Y, Yoshioka A, SHima M, KIRITA T: Intraoral hemostasis using a recombinant activated factor VII preparation in a hemophilia a patient with inhibitor. J Oral Maxillofac Surg 2003; 61: 1095-1097.

15. Satoh K, Окamoto M, Torimura A, Taguchi R: Successful Hemostasis after Dental Extraction withthe Use of Recombinant Activated Factor in a Factor Deficient Patient. Oral Sci Int 2006; 3: 10-12.

16. Scully C, WolfF A: Oral surgery in patients on anticoagulant therapy. Oral Surg Oral Med Oral Pathol Oral Radiol Endod 2002; 94: $57-64$.

17. Sumannuraks $M$, Chuansumrit $A$, Sriudomporn $N$ : The use of fibrin glue as an operative sealant in dental extraction in bleeding disorder patients. Haemophilia 1999; 5: 106-108.

18. Vinckier F, VermyLen J: Dental extractions in hemophilia: reflections on 10 years experience. Oral Surg Oral Med Oral Pathol 1985; 59: 6-9.

\section{Vajta L, Nagy Á, Kálovics J, Szalma J}

\section{Dental and oral surgical treatment of a B haemophilic patient with high inhibitor level Case report}

More than 1000 hemophilic male patients are registered in Hungary, from which only a trace number suffers from factor IX inhibitory hemophilia. For correct dental and oral surgical treatment of these patients mandatory cooperation is required among medical specialties, exerting multi-staged haemostatic principles. Authors represent in this case report the dental and oral surgical treatment of a B hemophilic patient with high inhibitor level and describe possible local haemostatic measures.

Keywords: bleeding disorders, hemophilia, haemostatic management, desmopressin, tranexamic acid, clotting factor substitution 